\title{
Agritourism Education and Research in Nepal
}

\author{
Shree Kumar Maharjan ${ }^{1 *}$ and Dharma Raj Dangol ${ }^{2}$ \\ ${ }^{1}$ Hiroshima University, Japan \\ ${ }^{2}$ Natural History Museum, Tribhuvan University, Nepal
}

Submission: February 17, 2018; Published: March 21, 2018

*Corresponding author: Shree Kumar Maharjan, Hiroshima University, Japan, Tel: +818062698826; Email: smilingsiri@gmail.com

\begin{abstract}
This paper reviews and highlights the agritourism research and education in Nepal and roles and contributions of Institute of Agriculture and Animal Science (IAAS) in promotion and development of agritourism education and research in Nepal. Furthermore, it also provides the prospects and potentials of agritourism education and research in Nepalese context. The paper endeavors the review and analysis of the literatures (both published and unpublished) produced in the institute vis-à-vis other available literatures in Nepalese context.
\end{abstract}

Keywords: Agritourism; Agriculture; Tourism; Nepal; IAAS

\section{Introduction}

Agritourism is a very new concept in the Nepalese context, despite long history of agriculture and tourism sectors in the country. In fact, agriculture remains the main source of livelihood and food security for more than $65 \%$ populations for many generations, whereas tourism became an important sector since in 1950 s after the increased flow of international tourists to explore the cultures, picturesque of Himalayan landscapes. In 1953, Edmund Hillary and Tenzing Norgay Sherpa conquered the Mt. Everest for the first time and Nepal became a popular destination for the international tourists $[1,2]$. There are many potentialities and popular forms of tourism industries in Nepal. However, there is no specific data on the history of agritourism development in Nepal. but, agriculture always remain an important sector in the tourism industry providing quality, healthy, organic and nutritious food for the tourists.

Agritourism is also known as agricultural tourism, agrotourism, agri-ecotourism, farm tourism, farm-based tourism, vacation farms, farm stays. Kokko [3] has identified numerous distinguished prospects and potentials of agritourism industry. For instance, the tea states in eastern Nepal have been famous for domestic and international tourists for recreational and beautiful landscapes. Furthermore, it is also popular for agricultural diversity in addition to tea states such as Aalu (potato), Alaichi (cardamom), Aduwa (ginger), Akabare khursani (red round big chilly), Olan (milk and milk product), and Amliso (broom) (Dangol, n.d.). Lack [4] emphasized on a successful diversification strategy by augmenting the farm business with tourism activities that is appropriate in Nepalese economy by using diversified resources, landscapes, biodiversity, cultural heritages, and unique traditions $[5,6]$. However, the scenario has been changing over the years since the agricultural labor forces, especially youth, are distracted from this sector which is an issue not only in Nepal, but also in many other developing and even developed countries. But, it is still continuing to be the backbone of nation's economy as it contributes nearly $47 \%$ to the Total Gross Domestic Product (GDP) in the country in 1991 World Bank [7], which reduced to $36 \%$ in 2011 [8].

Additionally, tourism has contributed the significant roles in overall development of the nation and also to uplift the living standards of the people $[9,10]$. Many researchers emphasized on the importance of increasing the length of tourists' stay Gautam \& Adhikari [10] and tourism in Nepal is also exploring new forms of tourism activities to lengthen the stay of tourists. In this context, agritourism can be new possibility in agriculture sector that motivates and encourages farming communities and also youths to raise the crops in an ecofriendly manner and diversity their economies by utilizing their traditional knowledge, conserving biodiversity and maintaining a rural and agricultural way of life [3].

This paper reviews and analyzes the published and unpublished literature on rural tourism and agritourism in Nepal and abroad. Number of publications relating to tourism, in general, was found, but very few publications related to agritourism in particular. The roles and contributions of Institute of Agriculture and Animal Science (IAAS) in promotion and development of agritourism is significant at the institutional level. 
Likewise, the roles of Prof. Dharma Raj Dangol are remarkable in development of the course on agritourism, networking with the related institutions and publications relating to agritourism. Prof. Dangol has published more than a dozen of journal articles, popular articles particularly focusing on agritourism in Nepal. After enrollment of agritourism course in the IAAS, the students and faculties published the popular and journal articles on agritourism in different magazines, periodicals, and journals both in Nepali and English languages. However, there is still limited research work specific to agritourism in Nepal. Those publications were reviewed and analyzed for this paper.

\section{Major Findings}

\section{Agritourism education}

Number of universities and tourism institutions are present in Nepal in recent years, but still wider gap and lack of coordination between these institutions to promote and enhance tourism and agritourism in particular. Tourism education and research is not developed to the level of tourism sector in Nepal (Asian Tour, n.d.). The knowledge and information on agritourism is still scanted particularly in demand side as most of agritourism studies are predominantly focus on characteristics of supply side even at the international level [11]. In Nepalese context, there are very limited information in both demand and supply sides. Very few private and public institutions have specific course on tourism and agriculture in Nepal. Prior to the course in IAAS under department of environmental science as a part of Masters in Conservation Ecology, there was almost null on agritourism course. Afterwards, students and faculties started research and publications on related issues despite the multiple issues and challenges. It was challenging to systematically run the course, since there are limited agritourism experts, researches and related publications.

Some tourism related organizations such as Nepal Tourism Board (NTB), Tourism for Rural Poverty Alleviation Programme (TRPAP), Nepal Academy of Tourism \& Hotel Management (NATHAM), Namsaling Community Development Center (NCDC), Local Initiatives for Biodiversity, Research and Development (LIBIRD) have positively collaborated and contributed in the promotion and development of agritourism by providing platforms in teaching-learning process. The educational approaches and methods applied for the course were practical by involving different experts in the sector, tourism related institutions for enhanced knowledge and understanding. Furthermore, the course was taught using the advanced technologies and audiovisual medias, real experiences in the fields. In addition, students and faculties received opportunities to experience the homestay at the community-based tourism sites. In that relation, both faculties and students received the advanced knowledge and skills on tourism and rural tourism in general and agritourism in particular. For effective promotion of agritourism and development of human resources, the formal and informal educational needs to incorporate it in their courses including conservation of traditional agricultural practices and land races $[12,13]$. The agritourism education is generally combined with entertainment mainly in agricultural tours, cooking and baking contest, concerts and musical events, cultural and heritage tours, visit to agricultural or ethnic museums, farm demonstrations, seasonal festivals, domestic and exotic animals [14]. Some of these events were also organized as part of agritourism education in IAAS.

Since, the course was introduced for the first time in the history of IAAS and also in the country, it is really difficult to find the experts in this particular field. At the same time, there weren't any specific agritourism packages or promotional activities prior to the introduction of the course in the IAAS. However, it is always interconnected with other forms of tourism such as ecotourism, rural or village tourism, trekking and adventurous tourism. Therefore, coordination between other forms of tourism and tourism related organizations and tourism experts are required for long-term agritourism plan Dangol [15] B.S. ). Furthermore, the policy on tourism 2052 B. S. also emphasized on linkages of tourism sector to the agriculture and cottage industries with indigenous knowledge for the overall development of the nation [16].

\section{Agritourism research and publications}

There were very little publications on agritourism prior to 1990; however, it became one of the interesting topics after 1991 that resulted two journals - Journal of Sustainable Tourism and Tourism Recreation Research, entirely dedicated to rural development and agritourism, but still very few academic articles had been published [4]. In Nepalese context, after the enrollment of the agritourism course, the students have developed and submitted research proposals and term papers, mainly based on review of the available literatures and researches particularly on agritourism, ecotourism and in the tourism sector, as part of the agritourism education. At the beginning of the course, it was indeed challenging to find the research papers and literatures on agricultural based tourism in Nepalese context, simply because there was very limited research work done in this field. In the new area of research, there are many challenges and opportunities at the same time; likewise, the challenges in the field of agritourism can be turn into opportunities. Intense and dedicated research and analysis is needed in agritourism research work. In initial stage, it requires targeted researches on agritourism and also in combination with other forms of tourism as well [16].

Later on, both students and faculties started to carry out researches (both field based and desk) on the topic and published in magazines, periodicals and journals that have enriched the

B.S. is Bikram Sambhat, a nepali calender, which is 57 years ahead than A. D. 
literature. However, as compared other fields, there are still very limited research and publications on agritourism, though there are some research and publication focused on ecotourism and rural tourism. Additionally, some tourism related organizations and institutions also started to promote and integrate agritourism packages and products in their regular programmes. For instance, Tourism for Rural Poverty Alleviation Programme (TRPAP) started to promote agritourism as an important component of the tourism in alleviating poverty in rural areas of Nepal. Furthermore, the TRPAP also provided small grant for students to carry out research on agritourism and ecotourism in 2005 as part of their thesis. Additionally, travel agencies in Pokhara have regularly started to celebrate 'Rice plantation day (Ropai Jatra)'. The related articles were also published in Nepal Travelers and Nepal Travel and Tourism Reporter (NTTR).

Likewise, other tourism related organizations and institutions have commenced research and promotional activities. As a result, many different forms of agritourism packages/attractions were introduced such as Ropai Jatra (Rice Plantation day/Festival), Bullock Races, by many organizations including Nepal Tourism Board and many travel agencies in Pokhara and other parts of the country. In fact, Nepal is only the country that celebrates national rice plantation day after UN declaration in 2004 as the international year for rice plantation [17]. Today, Ropai Jatra is being celebrated on 29 June every year in the various parts of Nepal including ploughing, singing folk songs, planting rice competitions and some other entertaining games.

\section{Theses on agritourism}

As part of the fulfillment of the course in the postgraduate, the students enrolled in Department of Environment Science had to submit thesis by carrying out research and analysis of the findings to the committee in the institute composes of Dean, Dean of examination including advisory members and defend their theses. Out of 14 students enrolled in the department of environmental science, 6 students conducted researches on agri-tourism and ecotourism for their theses since 2005. Out of which, 4 theses were directly focused on agritourism. 3 of these theses were concentrated in Chitwan district, and one conducted in Kirtipur, Kathmandu district, simply because it's easy to collect data in Chitwan since IAAS was located in the district. In that sense, only two districts out of 75 districts in Nepal are covered for the agritourism research, though there are lots of possibilities and prospects of agritourism industry as a new product throughout the country, but still needs to generate awareness among farmers and tourism entrepreneurs and develop required infrastructures $[15,18]$. There are many possibilities of promoting agritourism in different parts of the country such as Tea states in Eastern parts of Nepal, Buckwheat, mushroom and apple farming in high hills of Nepal, and rice farming in the Southern part of Nepal. The one village one product (OVOP) programme in Nepal also highly focused on promotion of agricultural products. The programme has identified 8 potential agricultural products such as Junar (sweet orange), Rainbow
Trout, Bel (stone apple), Lapsi (hug plum), Cymbidium Orchids, Agritourism, coffee and Lokta (daphne papyracea) in 11 districts [19], which shows the potentials and prospects of agritourism throughout the country, but need to carry out studies on the prospects of agritourism, since limited research has been carried out in agritourism aspects in Nepal [12,13].

\section{Promotion and development of Agritourism in Nepal}

One of the objectives of tourism vision 2020 of Nepal has prioritized the new investment in creating new tourism facilities, products and services (Bhandari, n.d., PowerPoint Presentation, MoTCA [1]. That's the reason, it has given emphasis on promoting new tourism products, extend tourism activities in remote and rural areas of the country and development of human resources through public and private educational institutes [1]. Agritourism can be one of the new tourism facilities, products and services if it can be packaged strategically $[2,12,13]$. Agritourism has become the main attraction and interest of the entrepreneurs and policy makers in recent decades. The changing scenario of tourism industry encouraged the agritourism at national and international level, thus expanding rapidly [20].

The periodic plan of the country has always prioritized agriculture and tourism sectors. Both of these important sectors in Nepalese context can be combined to develop new tourism product in Nepal. In fact, agriculture is always an important component of the tourism. In order to serve quality food and drinks for the tourism, it needs to be ensured good and healthy agricultural production in the country. Furthermore, the agriculture practices, way of plantation, harvesting, fishing, drying crops, aquaculture, animal farming, hunting among other can be packaged for agritourism products in the country. Currently, many of agriculture exhibitions at district and national level have been attracting large mass of domestic and international tourists, which shows huge potentials of agritourism industry in Nepal.

The tourism policy 1995 has specifically focused on the establishment of linkages between tourism and agro-based cottage industries and emphasis should be given to develop these related sectors simultaneously. It has further encouraged in local investments in service oriented, travel and trekking agency business to promote and transfer skills and technology [21]. In that connection, agritourism can be the perfect product to link the tourism and agro-based cottage industries including the local investment in the tourism sector. In fact, the community-based tourism with homestay programme is one of the new tourism programme in Nepal, which is the sustainable in the sense, it has created positive impacts on rural village development, rural women development, local economy, environment and entire community [22]. Within the community-based tourism, agriculture sector and commodities play an important role for its success, though in the past agritourism was not developed as separate tourism product in Nepalese context. However, it is now being developed as distinct tourism package in the country. 
There are many good examples of agriculture-based tourism or agritourism in the country. We can start the agritourism with Bisket Jatra in Bhaktapur, which is one of the famous festival in the Kathmandu valley, where large number of tourists (both domestic and international) visit every year. Similarly, there are agricultural offices, horticultural farms, nursery farms, fishing farms in different parts of the country. In fact, the Nuwakot is well known for Rainbow trout fish, Ilam is famous for tea states, Recently, Ropai Jatra is gaining popularity over the years. Many government and non-government organizations are now celebrating national rice plantation day (Ropai Jatra) annually, where large number of tourists are getting involved [23-26].

\section{Conclusion}

Agritourism has been rapidly expanding at the international level and to some extent in Nepal as well. However, agritourism research and education hasn't rapidly expanding in the same rate. The initiative of Institute of Agriculture and Animal Science (IAAS) to develop and promote the new courses including agritourism in master's and $\mathrm{Ph}$. D. degree is much appreciated and acknowledge based on the changing contexts. These courses are studied by number of students who have been engaged at different national and international levels after completion of the courses. Students learned many innovative and life skills under these new courses such as writing proposals to seek fund support for research, writing and publishing articles, participating different seminars, training and workshops, networking with different organizations and so on. In addition, it's also new for the faculties, since they are also not trained to these new courses, however many faculties struggled hard to regularly update on the courses and provide up-to-date information and recent knowledge to the students.

The course on agritourism was also linked with many organizations such as NTB, NATHM and TRPAP etc. basically to provide the overall scenario of tourism industry in Nepal. However, it was very hard to get the concrete cases of agritourism in Nepalese context. It is directly or indirectly linked to other forms of tourism such as rural/village tourism, ethnic or cultural tourism, sport tourism, adventure tourism etc. after all food comes from agriculture sector for all forms of tourism. Since the nation is searching for new tourism packages and destination, agritourism can be stand-alone tourism package for the tourism industry in Nepal which will definitely extend the length of international tourists' stay and diversity new taste for the domestic tourism in Nepal.

\section{Acknowledgement}

The authors would like to acknowledge the efforts and contributions of all faculty members in Department of Environment Science in the process of passing the new courses in the institute. Furthermore, the authors extend deep gratitude to the subject matter committee (SMC) in the institute for approval of the courses. Finally, sincere appreciate to all the students enrolled in the courses and carrying out the researches and publication under the guidance of the faculties.

\section{References}

1. MoTCA (2009) Tourism Vision 2020. Ministry of Tourism and Civil Aviation (MoTCA), Government of Nepal, Kathmndu, Nepal.

2. Shrestha HP, Shrestha P (2012) Tourism in Nepal: A Historical Perspective and Present Trend of Development. Himalayan Journal of Sociology and Anthropology 5: 54-75.

3. Kokko A (2011) An Exploration of Agritourism: Topics, Literature and Areas for Future Research.

4. Lack KJ (1997) Agritourism Development in British Columbia. Masters Thesis submitted to School of Resource and Environmental Management. Simo Fraser University, USA.

5. Thapa D (2013) Development of Agrotourism Nepal, An Alternative to Emigration for Nepalese Youths. Case: Bishram Batika Restaurant, Thesis submitted to Centria University of Applied Science.

6. Maharjan SK (2006) Prospects of agritourism in Chitwan. Nepal Travel Trade Reporter 9(22): 26-29.

7. World Bank (2008) Nepal Country Overview 2008.

8. MoAC (2011) Retrieved from Ministry of Agriculture and Cooperatives (MoAC).

9. Khanal SP (1986) Tourism industry and its share in national income of Nepal (Nepal reference to the importance of its sector), Dissertation, M.A. Faculty of Humanities and Social Science, Central Department of Economics, Tribhuvan University, Kirtipur, Nepal.

10. Gautam B, Adhikari N (2005) Village tourism: prospects and problems. Nepal Travel Trade Reporter 9(1): 26-29.

11. Santeramo FG, Barbieri C (2017) On the demand for agritourism: A cursory review of methodologies and practice. Tourism Planning \& Development 14 (1): 139-148.

12. Maharjan SK (2006) Study on development and promotion of agritourism in Shaktikhor VDC of Chitwan district, Institute of Agriculture and Animal Science, Rampur, Chitwan, Nepal.

13. Maharjan SK (2014) Development and promotion of the agritourism in Chitwan, Nepal. LAMBERT Academic Publishing, Nepal.

14. CCD (2011) Agritourism. Center for Crop Diversification, College of Agriculture, Food and Environment, University of Kentucky, USA.

15. Shrestha YM (2005) Prospecting Agritourism in Ilam: Concept, Issues, Challenges and Unlimited Opportunities. Term paper submitted to the Department of Environmental Science, Institute of Agriculture and Animal Science, Tribhuvan University, Chitwan, Nepal.

16. Dahal OP (2060) Rural Tourism. Nima Pustak Prakashan, Kathmand, Nepal.

17. NTTR (2006) Third Asar Festival. Nepal Travel Trade Reporter 9(28): 11.

18. Pant A (2002) Tourism development and economic impacts in Nepal. Thesis, M.A. Faculty of Humanities and Social Sciences, Tribhuvan Univeristy, Kirtipur, Nepal.

19. Shakya G (2008) Concept and Implementation of OVOP. Sherpa, M. N. 2004. Nepal pioneering in pro-poor tourism development for livelihood change. In: CN Kanel (Ed.), Rural Tourism Features. Tourism for Rural Poverty Alleviation Programme, (TRPAP), pp. 35-38.

20. Gaetano SF, Mariangela M (2014) Enhancing the foreign demand for agritourism. pp. 33-42.

21. FNCCI (2014) Tourism Policy 1995 (unofficial translation), Government policies and acts. Federation of Nepalese Chambers of Commerce and 
Industries.

22. Lama M (2013) Community Homestay programmes as a form of Sustainable Tourism Development in Nepal. Thesis submitted to Centria University of Applied Sciences, Degree Programme in Tourism.

23. Asian Tour Nepal Tourism Sector Analysis. Asia Invest Programme UP ZRS Universa Na Primorskem and Enterprise Europe Network.
European Union.

24. Bhandari KR Tourism Policies and Priorities. Powerpoint Presentation, Nepal Tourism Board.

25. Dangol DR Prospects of Agritourism in Ilam: Concept, Issues, Challenges and Unlimited Opportunities.

Your next submission with Juniper Publishers will reach you the below assets

- Quality Editorial service

- Swift Peer Review

- Reprints availability

- E-prints Service

- Manuscript Podcast for convenient understanding

- Global attainment for your research

- Manuscript accessibility in different formats

( Pdf, E-pub, Full Text, Audio)

- Unceasing customer service

Track the below URL for one-step submission https://juniperpublishers.com/online-submission.php 